\title{
Determinant Factors Influencing eWOM
}

\author{
Asst. Prof. Dr. Aysen Akyüz \\ Beykent University-Istanbul; aysenakyuz@beykent.edu.tr
}

\section{Doi:10.5901/mjss.2013.v4n11p159}

\begin{abstract}
Many studies demonstrated that Internet penetration and time spent online increased considerably in Turkey. However, there are not enough studies focusing on users attitudes towards e-Word of Mouth. E-Word Of Mouth is seen as more credible than other marketing communications since it comes directly from other consumers. eWOM shows high accessibility compared to traditional WOM, therefore its tools such as online recommendations, reviews or product ratings, are used more often and it makes eWOM more powerful. Thus, it is important to understand online users' behaviors, particularly for those who participates in social networks and engage in eWOM in this environment. Clearly findings in this area will help and facilitate marketer's media selection to reach out its potential customers and align their marketing efforts in most efficient way. This study examines user's attitudes towards eWOM and looks at factors influencing eWOM. An online survey conducted among Internet users provides further evidence for increasing popularity of eWOM and demonstrates the power of eWOM in Turkey. Perceived eWOM Credibility and Customer Susceptibility to Interpersonal Influence appears to be significant factors impacting eWOM.
\end{abstract}

Keywords: electronic word of mouth, customer susceptibility, perceived credibility, eWOM effect, experience of online review usage, online review

\section{Introduction}

Word of Mouth is a considerably effective communication tool that has a unique position in respect to marketers. The one who starts the word of mouth communication is the consumer. Individuals express their positive or negative opinions and give advices to each other about a restaurant where they have their lunch at, a book that they find interesting or a store where they buy good quality products at a good price. Since it is carried out among acquaintances, friends or family members, it has never been perceived commercial by the consumers, and it plays a major role in the purchase decisionmaking process of a consumer. Santo (2006) states that word of mouth cuts through and rises beyond the message noise since it has been sent from a source such as a friend or a co-worker.

Word of mouth is a primary factor behind 20 to 50 percent of all purchasing decisions. Its effect is greatest when consumers are buying a product for the first time or when products are relatively expensive, and some other factors that tend to make people conduct more research and seek more opinions (Bughin et. al, 2010). The influence of WOM is also high, when there is a strong tie between the individuals that exchange information (Brown \& Reingen, 1987).

The internet has changed the traditional communication model for the companies. The innovation of Web 2.0 technology enabled users to socially interact online by generating and sharing content, sharing thoughts and opinions with each other. Electronic recommendations and appraisals like a review about a book, via electronic word of mouth are effective ways to have a product promoted via interaction. According to Hennig-Thurau et.al. (2004, p.39), the advance of the internet technology has extended consumers' options for gathering unbiased product information from other consumers and thus consumers have the opportunity to offer their consumption related advices by engaging in eWOM.

This study examines the determinant factors influencing eWOM in order to narrow the gap in the literature and thus applies regression analysis based on factor dimensions of Park et.al. (2011)'s study."

\section{Electronic Word Of Mouth}

Traditional WOM has become an important subject for the researchers over the years and it is possible to find many definitions regarding this concept. Arndt $(1967$, p.3) defined traditional Word of Mouth as: "Oral, person to person communication between a receiver and a communicator whom the receiver perceives as non-commercial, concerning a brand, a product, or a service". In another definition, Dwyer (2007, p.64) touched on the social aspect of WOM and 
defined it as follows: "Word of mouth is a network phenomenon: People create ties to other people with the exchange of units of discourse (that is, messages) that link to create an information network while the people create a social network".

WOM, has a major role in consumer buying decision process. Recommendations from people are a much more important influence than formal advertisements (Katz and Lazarsfeld, 1955, p.176-179). The reason of the success of WOM is obvious: WOM is perceived as reliable by the consumers compared to the communication efforts of the marketers because information is provided to them via the objective comment of another consumer (Allsop et.al, 2007). Since the receiver of a word of mouth message trusts the sender, it lowers any anxiety, vulnerability and uncertainty about a particular transaction (Augusto de Matos \& Rossi, 2008).

While WOM has always played an important role in the formation of consumer opinions, over the past decade it has become an even more powerful source due to the technological explosion of informal communication channels such as the internet, instant messaging, blogs (Allsop et.al, 2007). According to Korgaonkar and Wolin' (1999), the interactive structure of web has made the consumer more active. User chooses which web sites he/she will review and knows with whom he/she will be in interaction and what he/she wants to transfer to the others. The socialization factor represents the role of the Web as a facilitator of interpersonal communication. Consumers consider the web as place where they socialize and are in interaction with those having similar fields of interest. eWOM, being the extension of traditional Word of Mouth, can be defined as "any positive or negative statement made by potential, actual, or former customers about a product or company, which is made available to a multitude of people and institutions via the Internet" (Hennig-Thurau et al., 2004, p.39).eWOM communication can take place in various settings. Consumers can post their opinions and reviews about a product on weblogs, social networking sites, discussion forums, review websites, etc. (Cheung and Tadani, 2010, p.330).

According to Dichter (1966), "Word of Mouth" behavior satisfies the requirement of individuals to make an important share for other consumers. On the other hand, Engel, et al. (1993) stated that the reason of consumers' transferring information to other individuals is the intimate intention for assisting individuals in making a more correct purchase decision.

\section{3. eWOM effect}

For consumers, it is important to listen to the opinions, advices of the others before or during their shopping. While they do this with their acquaintances, family members and friends in traditional WOM, may obtain the information they want by being in interaction with the consumers who they do not know but with whom they share similar interests in online WOM. Now, almost every website that makes online sales provides the opportunity of writing/reading online customer review to the consumer and also provides the opportunity of receiving/presenting information and advice. While making the purchase decision, many consumers are influenced from these comments and ratings, and adopt a positive or negative attitude for the product.

A helpful customer review is "a peer-generated product evaluation that facilitates the consumer's purchase decision process" (Mudambi and Schuff ,2010, p.186). As Lusky (2012) indicates, seventy percent of consumers worldwide trust online reviews, while only 47 percent believe traditional broadcast and print ads, according to a Nielsen (a global provider of insights about consumer watching and buying preferences) study. In the same study it has been found that consumer trust of online reviews has increased 15 percent in the last four years. On the contrary, the believability of paid TV, newspaper and magazine ad has declined.

Park et al (2011) defined eWOM effect as "the effect by eWOM to affect purchase decision making". eWOM effect is going to be the dependent variable in our study.

\section{Customer susceptibility to interpersonal influence}

As Iqbal and Ismail (2011) states, customer susceptibility to interpersonal influence is the need to identify or enhance one's image with significant others through the acquisition and use of products and brands, the willingness to confirm to the expectation of the others regarding purchase decision, and services by observing others or seek information from others. Mourali, Laroche, and Pons (2005: Frederics, 2008) found support for a positive relationship between consumers' informational susceptibility to interpersonal influence and a preference for personal sources when seeking productrelated information. According to Frederics (2008), this suggests that the easier a consumer is influenced, the more they favor WOM sources when seeking information. They trust the information provided by personal sources to be accurate. The direct availability of WOM sources and low cost of finding WOM information on the Internet is suggested to 
overweight the possible disadvantages perceived by consumers. Therefore, it is expected that people who spread online WOM and in addition are highly susceptible to interpersonal influence are more likely to be affected by online WOM .

As Park et.al (2011, p.75) also states there is a positive relation between customer susceptibility to interpersonal influence.

H1. Customer susceptibility to interpersonal influence has a positive impact on eWOM effect.

\section{Experience of online review usage}

In accordance with the Media Dependency theory, a media dependency relationship is one "in which the satisfaction of needs or the attainment of goals by individuals is contingent upon the resources of the other party" (Ball-Rokeach and DeFleur 1976, p. 6). Hence, the individuals have to trust the media information resources in order to achieve various objectives in today's society. (Loges and Ball-Rokeach 1993). Park et al (2011, p.75) states in parallel with Media dependency theory that, the individuals who make online shopping by referring frequently to the online reviews are more willing to use and spread the online review.

Accordingly,

$\mathrm{H} 2$ : Experience of online review usage has a positive impact on eWOM effect.

\section{Perceived credibility}

Flanagin and Metzger (2008, p. 8) defines the term "credibility" as the believability of a source or message, which is made up of two primary dimensions: trustworthiness and expertise.

Wathen and Burkell (2002) stated that source credibility is a basic factor which facilitates the judgment of the consumer about online information. A user's first task is to rate the credibility of the medium itself based on its surface characteristics such as appearance and interface design. The second task for the online user is rating the source and the message content. The evaluation of a source is often made in terms of its expertise/competence, trustworthiness, credentials, and so forth. The message is evaluated in terms of content, relevance, currency, accuracy, and tailoring. The last stage of the process, involves assessing the interaction of presentation and content with the consumer's cognitive state, which is determined from the consumer's experience and acknowledgement.

According to Cheung et al (2007), in eWOM context, the user will get some information from the review and will use the review if he/she perceives the product comment/advice as credible. On the other hand, the individual will not take the review into consideration in order to avoid the potential risks if he/she perceives the product comment/advice as less credible.

Thus,

H3. Perceived credibility has a positive impact on eWOM effect.

\section{Methodology}

The purpose of this study is to explore the factors influencing Word of Mouth communication. In the questionnaire section of the study, the factors influencing word of mouth are measured, based on the structural model of "Factors Influencing eWOM effects: Using Experience, Credibility, Susceptibility" which was written by Park et al.in 2011, and the hypotheses and survey questions were created accordingly.

A questionnaire was used as data collecting instrument. The questionnaire that constitutes the research questions of the study was prepared as one form that is comprised of two sections. The first section is made up of multiple-choice questions, and the second section includes 5 point likert scale questions. The participants assess the suitability of the expressions on the likert scale. The answers given to the adjectives were carried out by granting 5 points to the choice "I strongly agree" and by granting 1 point to the choice "I strongly disagree". In the first section of the questionnaire, there were 6 questions regarding the demographics and the user profile of the respondent. In the second part, 11 questions were asked regarding the factors influencing eWOM. The data collection process of the research was carried out between 17 June and 20 June 2013. The selection of those participating in the questionnaire was made by using simple sampling method. The sample of the study is drawn from social media users. Within the above mentioned period, the respondents were reached via Facebook, Twitter and Linkedin, and it was requested to answer the questionnaire by giving link to Webanketa site where the questionnaire was hosted. Within the indicated term, totally 251 questionnaires were completed and analyses were made on this number. IP protected limitation was arranged in order to enable the 
completion of the questionnaire for only once by each user.

\section{Findings}

SPSS 17.0 Statistical package program is used for the statistical analyses. When the data is assessed, descriptive statistical methods are used. Pearson Correlation analysis is used in order to detect the relations among variables. Linear Regression analysis is used in order to examine the effect of independent variables on the dependent variable.

Table 1. Demographic Profile of the Sample

\begin{tabular}{|l|l|c|c|}
\hline & & N & $\%$ \\
\hline \multirow{5}{*}{ Age } & $18-24$ & 91 & 36,3 \\
\cline { 2 - 4 } & $25-34$ & 85 & 33,9 \\
\cline { 2 - 4 } & $35-44$ & 57 & 22,7 \\
\cline { 2 - 4 } & $45-54$ & 9 & 3,6 \\
\cline { 2 - 4 } & $55-64$ & 8 & 3,2 \\
\cline { 2 - 4 } & 65 and over & 1 & 0,4 \\
\hline \multirow{5}{*}{ Education Level } & Male & 106 & 42,2 \\
\cline { 2 - 4 } & Female & 145 & 57,8 \\
\hline & Doctoral degree & 8 & 3,2 \\
\cline { 2 - 4 } & Primary education degree & 3 & 1,2 \\
\cline { 2 - 4 } & High school graduate & 29 & 11,6 \\
\cline { 2 - 4 } & Bachelor's degree & 180 & 71,7 \\
\cline { 2 - 4 } & Master's degree & 31 & 12,4 \\
\hline \multirow{5}{*}{ Profession status } & Unemployed & 13 & 5,2 \\
\cline { 2 - 4 } & Retired & 9 & 3,6 \\
\cline { 2 - 4 } & House wife & 15 & 6,0 \\
\cline { 2 - 4 } & Wage earner in public sector & 19 & 7,6 \\
\cline { 2 - 4 } & Student & 87 & 34,7 \\
\cline { 2 - 4 } & Wage earner in private sector & 90 & 35,9 \\
\cline { 2 - 4 } & Self-employment & 18 & 7,2 \\
\hline \hline \multirow{5}{*}{} & & & \\
\hline
\end{tabular}

$\% 33,9$ of the respondents are between the ages $25-34$ and $\% 36,3$ of them are between the ages $18-24 . \% 42,2$ of the sample are male and \% 57,8 of them are female. \% 12,4 own master's degree and \% 71,7 of the respondents have bachelor's degree. \% 34,7 of them are students and \%35,9 of the respondents are wage earners in private sector.

Table 2. Time spent on internet

\begin{tabular}{|l|c|c|}
\hline & N & $\%$ \\
\hline Less than 1 hour & 7 & 2,8 \\
\hline 1-2 hours & 38 & 15,1 \\
\hline 2-3 hours & 59 & 23,5 \\
\hline 3-4 hours & 50 & 19,9 \\
\hline 4-5 hours & 36 & 14,3 \\
\hline 5 hours and over & 61 & 24,3 \\
\hline
\end{tabular}

Most of the respondents (\% 24,3) spend 5 hours and over on internet per day. 
Table 3. Reasons consumers go on to internet

\begin{tabular}{|l|c|c|}
\hline & N & $\%$ \\
\hline Connect with friends and family in Social networking sites & 221 & 88 \\
\hline Read magazines and newspapers online & 190 & 75,7 \\
\hline Share an information & 175 & 69,7 \\
\hline Share photos, videos, etc. & 132 & 52,6 \\
\hline Gain information about a product/brand & 130 & 51,8 \\
\hline Online shopping & 129 & 51,4 \\
\hline Read product/service reviews & 101 & 40,2 \\
\hline Share opinions about a product/brand & 76 & 30,3 \\
\hline Play games & 64 & 25,5 \\
\hline Other & 38 & 15,1 \\
\hline
\end{tabular}

It is revealed that the subjects spend their times on internet mostly for connecting with friends and family in SNSs (\% 88).

Table 4. Correlation Analysis

\begin{tabular}{|c|c|c|c|c|}
\hline & eWOM effect & $\begin{array}{c}\text { Experience of online } \\
\text { review usage }\end{array}$ & $\begin{array}{l}\text { Perceived } \\
\text { credibility }\end{array}$ & $\begin{array}{l}\text { Customer susceptibility } \\
\text { to interpersonal influence }\end{array}$ \\
\hline eWOM effect & 1 & & & \\
\hline $\begin{array}{l}\text { Experience of online } \\
\text { review usage }\end{array}$ & $\begin{array}{c}0,526 \\
\left(0,000^{* * *}\right)\end{array}$ & 1 & & \\
\hline Perceived Credibility & $\begin{array}{c}0,686 \\
\left(\mathbf{0}, \mathbf{0 0 0} 0^{\star * *}\right)\end{array}$ & $\begin{array}{c}0,599 \\
\left(0,000^{* * *}\right)\end{array}$ & 1 & \\
\hline $\begin{array}{l}\text { Customer susceptibility to } \\
\text { interpersonal influence }\end{array}$ & $\begin{array}{c}0,713 \\
\left(0,000^{* * *}\right)\end{array}$ & $\begin{array}{c}0,545 \\
\left(0,000^{* * *}\right)\end{array}$ & $\begin{array}{c}0,721 \\
\left(0,000^{\star * *}\right)\end{array}$ & 1 \\
\hline
\end{tabular}

Experience of online review usage and eWOM effect are positively correlated at the level of $\% 52,6 \quad(r=0,526$; $p=0,000<0,05)$. Perceived credibility and eWOM effect are positively correlated at the level of $68,6 \%(r=0,686$; $p=0,000<0,05)$. Customer susceptibility to interpersonal influence and eWOM effect are positively correlated at the level of $71,3 \%$ ( $r=0,713 ; p=0,000<0,05)$.

As a result of the correlation analysis which is made to determine the relation between perceived credibility and experience of online review usage, a positively significant relation at the level of $59,9 \%$ is found $(r=0,599 ; p=0,000<0,05)$. Accordingly; as the perceived credibility increases, experience of online review usage also increases.

As a result of the correlation analysis which is made to determine the relation between Customer susceptibility to interpersonal influence and Experience of online review usage, a positively significant relation at the level of $54,5 \%$ is found. ( $r=0,545 ; p=0,000<0,05)$. Accordingly; as Customer susceptibility to interpersonal influence increases, experience of online review usage also increases.

As a result of the correlation analysis which is made to determine the relation between Customer susceptibility to interpersonal influence and perceived credibility, a positively significant relation at the level of $72,1 \%$ is found. ( $r=0,721$; $p=0,000<0,05)$. Accordingly; as Customer susceptibility to interpersonal influence increases, perceived credibility also increases. 
Table 5. Regression Analysis

\begin{tabular}{|c|c|c|c|c|c|c|c|}
\hline $\begin{array}{l}\text { Dependent } \\
\text { variable }\end{array}$ & Independent variables & ß & $T$ & $\mathrm{p}$ & $F$ & $\begin{array}{c}\text { Model } \\
\text { (p) }\end{array}$ & $\mathrm{R}^{2}$ \\
\hline \multirow{4}{*}{ eWOM effect } & Constant & 0,919 & 5,426 & 0,000 & \multirow{4}{*}{112,152} & \multirow{4}{*}{0,000} & \multirow{4}{*}{0,572} \\
\hline & $\begin{array}{l}\text { Experience of online } \\
\text { review usage }\end{array}$ & 0,097 & 1,974 & $0,049^{*}$ & & & \\
\hline & Percieved credibility & 0,300 & 4,911 & $0,000^{* \star *}$ & & & \\
\hline & $\begin{array}{l}\text { Customer susceptibility to } \\
\text { interpersonal influence }\end{array}$ & 0,416 & 7,052 & $0,000^{* * *}$ & & & \\
\hline
\end{tabular}

The regression analysis which is made to determine the relation among experience of online review usage, perceived credibility, customer susceptibility to interpersonal influence and eWOM effect is found statistically significant ( $F=112,152$; $p=0,000<0.05$ ). It is seen that the relation of it with the variables of experience of online review usage, perceived credibility, customer susceptibility to interpersonal influence as the determinant of eWOM effect is very strong in terms of explanatory power $\left(R^{2}=0,572\right)$. The experience of online review usage, increases the eWOM effect level $(B=0,097)$. The perceived credibility, increases eWOM effect level $(ß=0,300)$. The Customer susceptibility to interpersonal influence, increases eWOM effect level $(ß=0,416)$.

Table 6. Item analysis

\begin{tabular}{|l|c|c|c|c|c|}
\hline & N & Av & Sd & Min. & Max. \\
\hline I always read online reviews written by others & 251 & 3,865 & 0,966 & 1 & 5 \\
\hline I always write down online review about the product I purchased & 251 & 3,048 & 1,219 & 1 & 5 \\
\hline I always read online consumer reviews before I purchase a product. & 251 & 4,255 & 0,995 & 1 & 9 \\
\hline I believe online review is a credible information source. & 251 & 3,641 & 0,929 & 1 & 5 \\
\hline I believe online review is an important information source. & 251 & 3,813 & 0,917 & 1 & 5 \\
\hline I believe online review is written under responsibility. & 251 & 3,470 & 0,939 & 1 & 5 \\
\hline If online reviews of a product are positive, I purchase it. & 251 & 3,590 & 0,901 & 1 & 5 \\
\hline I rely on online reviews when I purchase a product. & 251 & 3,546 & 0,858 & 1 & 5 \\
\hline Online reviews affect my purchase decision crucially. & 251 & 3,717 & 0,961 & 1 & 5 \\
\hline I like listening advices before shopping. & 251 & 4,056 & 0,808 & 1 & 5 \\
\hline Others' advices are important for my shopping. & 251 & 3,801 & 0,89 & 1 & 5 \\
\hline
\end{tabular}

It is seen that those participating in the research highly agree with the expression "I always read online reviews written by others " $(3,865 \pm 0,966)$; moderately agree with the expression "I always write down online review about the product I purchased" (3,048 $\pm 1,219)$; very highly agree with the expression "I always read online consumer reviews before I purchase a product." $(4,255 \pm 0,995)$; highly agree with the expression "I believe online review is a credible information source." (3,641 $\pm 0,929)$; highly agree with the expression "I believe online review is an important information source." $(3,813 \pm 0,917)$; highly agree with the expression "I believe online review is written under responsibility. " $(3,470 \pm$ 0,939); highly agree with the expression "If online reviews of a product are positive, I purchase it. " $(3,590 \pm 0,901)$; highly agree with the expression "I rely on online reviews when I purchase a product. " $(3,546 \pm 0,858)$; highly agree with the expression "Online reviews affect my purchase decision crucially." $(3,717 \pm 0,961)$; highly agree with the expression "I like listening advices before shopping." $(4,056 \pm 0,808)$ and highly agree with the expression "Others' advices are important for my shopping. " $(3,801 \pm 0,890)$.

Table 2. Summary of Hypothesis

\begin{tabular}{|l|c|}
\hline Hypothesis & Results \\
\hline H1. Customer susceptibility to interpersonal influence has a positive impact on eWOM effect. & Supported \\
\hline H2: Experience of online review usage has a positive impact on eWOM effect. & Supported \\
\hline H3: Perceived credibility has a positive impact on eWOM. & Supported \\
\hline
\end{tabular}




\section{Conclusion}

Today, WOM is not limited to just face to face communication. Along with the developments in the technology, the consumer is just a click away from the consumer comments, advices and rates regarding to a product or service he/she wants to purchase. WOM, with its existence and power in the communication can never be denied, thus it has been brought to another dimension. Now, there is no need of a friend or an acquaintance to disseminate a WOM message. The individuals take into consideration the comments made by other individuals with whom they share the same field of interest and which they perceive as credible. This effects their attitude towards a product or service positively or negatively. This study examines user's attitudes towards eWOM and determines the factors influencing eWOM effect.

A questionnaire was applied, and the results were assessed with linear regression and correlation analysis. The regression analysis which was made in order to determine the relationship among "Experience of online review usage" dimension, "perceived eWOM credibility" dimension, "customer susceptibility to interpersonal influence dimension" and the eWOM effect was found statistically significant.

It was found out that the relationship of "experience of online review usage", "perceived e WOM credibility", and "customer" susceptibility to interpersonal influence" as the determinants of eWOM effect was very strong in terms of explanatory power. The "experience of online review usage" dimension increases eWOM effect; "consumers' perceived eWOM credibility" dimension increases eWOM effect; "Customer susceptibility to interpersonal influence" dimension increases eWOM effect. Thus; all of the hypotheses were accepted.

On the other hand, the survey included 251 people and the answerers were found through Facebook, Linkedin, Twitter social networks. This limits to generalize the findings to some extent. In the future studies to be carried out regarding the subject, it may be more suitable to expand the field as well as the participant profiles and to undertake research with a more heterogeneous group.

\section{References}

Allsop, D.T., Bassett, B.R., Hoskins, J.A. (2007). Word of mouth research: Principles and Applications. Journal of Advertising Research. December. Vol.47 No.4. 398-411.

Arndt, J. (1967). Word of mouth advertising - a review of the literature. New York: Advertising research foundation.

Augusto de Matos, C., Rossi, C. A. V. (2008). Word-of-Mouth communications in marketing: a meta-analytic review of the antecedents and moderators. Journal of the Academic MarketingScience. Vol. 36. pp. 578-596.

Ball-Rokeach, S.J., \& DeFleur, M.L. (1976). A dependency model or mass-media effects. Communication Research. 3. pp:3-21.

Brown, J. J. \& Reingen, P. H. (1987). Social Ties and Wordof-Mouth Referral Behavior. Journal of Consumer Research. 14. pp: 35062.

Bughin, J., Doogan, J., \& Vetvik, O.J. (2010). A new way to measure word-of-mouth marketing. McKinsey Quarterly, April 2010. Retrieved June 28, 2013, from http://www.mckinseyquarterly.com/A_new_way_to_measure_word-of-mouth_marketing_2567

Cheung, M., Luo, C., Sia, C., and Chen, H. (2007) .How do people evaluate electronic word of mouth? Informational and normative based determinants of perceived credibility of online consumer recommendations in China. 11th Pasific-Asia Conference on Information Systems. pp:69-81.

Cheung, C.M.K., Thadani, D.R. (2010). The effectiveness of e-wom communication: A Literature Analysis. 23rd Bled e-Conference. June 20-23.

Dwyer, P. (2007). Measuring the value of electronic word of mouth and its impact inconsumer communities. Journal of Interactive Marketing. Vol. 21. No. 2. pp. 63-79.

Dichter, E. (1966). "How word-of-mouth advertising works?" Harward Business Review. 44. s:147-157.

Engel, J.F. ve Blackwell, R.D., Miniard, P.W. (1993). Consumer Behavior. Fort Ward:Dreyden Press. 8th edition.

Flanagin, A. J., \& Metzger, M. J. (2008). Digital media and youth: Unparalleled opportunity

and unprecedented responsibility (pp. 5-27). In M. J. Metzger \& A. J. Flanagin (Eds.),Digital media, youth, and credibility. Cambridge, MA: MIT Press.

Frederics, V. (2008). Online Word of mouth. The relationship between its two components: seeking and articulation. Universiteit Maastricht-Master's thesis. Retrieved June 26, 2013, from

http://arno.unimaas.nl/show.cgi?fid=11408

Hennig-Thurau T., Gwinner K.P., Walsh G., Gremler D.D. (2004) Electronic Word-of Mouth via Consumer-Opinion Platforms: What Motivates Consumers to ArticulateThemselves on the Internet? Journal of Interactive Marketing : Vol.18 No.1. pp: 38-52.

Iqbal, S., İsmail, Z. (2011). Buying Behavior: Gender and Socioeconomic Class Differences on Interpersonal Influence Susceptibility. International Journal of Business and Social Science. Vol 2. No.4. p:55-66

Korgaonkar, P., Wolin, L. (1999). A Multivariate Analysis of Web Usage. Journal of Advertising Research, Vol. 39. No. 2. pp. 53-68.

Loges, W.E. \& Ball-Rokeach, S.J. (1993). Dependency relations and newspaper readership. Journalism Quarterly. Vol 70. No.3. pp: 602-614. 
Lusky, Mark. (2012). Online reviews, word-of-mouth and recommendations generate the most marketing trust. Denver Business Journal. Retrieved June 25, 2013, from

http://wwww.bizjournals.com/denver/blog/broadway_17th/2012/11/online-reviews-word-of-mouth-and.html?page=all

Mourali, M., Laroche, M., \& Pons, F. (2005). Antecedents of consumer relative preference for interpersonal information sources in prepurchase search. Journal of Consumer Behaviour. Vol. 4. No.5. pp: 307-318.

Mudambi, S.M. , Schuff,D. (2010).What makes a helpful online review? A study of customer reviews on Amazon.com . MIS Quarterly Vol. 34. No. 1. pp. $185-200$

Park, C., Wang,Y., Yao,Y., Kang, Y.R. (2011). Factors influencing e-WOM effects: Using experience, credibility and susceptibility. International Journal of Social Science and Humanity. Vol.1. No.1.pp:74-79.

Santo, B. (2006). Multichannel Merchant. Color Photographs. Vol. 2 Issue 2. Pp. 28-30.

Wathen, C. N., \& Burkell, J. (2002). Believe it or not: Factors influencing credibility on the Web. Journal of the American Society for Information Science and Technology. Vol.53. No.2. pp: 134-144. 